\title{
Impact of non-performing assets on profitability in Nepalese Commercial Banks
}

\author{
Pokharel Shiva Prasad \& Pokharel Bishnu Prasad
}

\begin{abstract}
The degree of non-performing assets (NPAs) best demonstrates the adequacy of the financial part of a nation. The amount of non-performing assets affects not only the banking industry but also the total financial system and the economy of the country. The motivation behind this investigation is a push to evaluate the effect of Non Performing Assets on the profitability of Nepalese commercial banks. The study cover the period 2013 July 16 to 2018 July 16. Further, the examination is made to investigate the impact of various gatherings of banks. In particular, Government owned bank and private area banks on the financial business in such manner. Five out of twenty four individual private division banks and one out of three, government claimed banks have been considered with the end goal of the investigation for as sample. The investigation depends on optional information gathered from the Nepal Rastra Bank's site just as yearly report of concern banks.

To beat the examination objective clear measurements are utilized to portray the essential highlights of the information in the investigation, and inferential insights have been utilized to get to the effect of non-performing assets on profitability of the banks. Besides, credit deposit ratio, employee expenses over all out operating expenses and gross non-performing assets have been taken in to thought as free factor and Return on assets and earnings per share are a piece of ward variable. The appraisal of private part banks uncovers that the development pace of NPAs is low when contrasted with the administration claimed Agriculture Development Bank. The administration claimed bank has neglected to deal with the issue of unsecured loan adequately because of which the development in such loans has been marvelously high. Besides, the effect of NPA on profitability has been done as positive in relationship.
\end{abstract}

Key words: Return on assets; Non-performing assets; Earning per share; Credit deposit ratio; Profitability

\section{Introduction}

Banking in present age is the existence blood of whole monetary exercises. It is instrumental in encircling the financial fate of the nation. Banks activates assets from perfect part to profitable division. Since the banks have immense speculation potential, they can make a critical commitment in wiping out destitution and issue of joblessness. It can likewise 
acquire balance the between region, between division and between close to home differences in creating nation (Nachimuthu \& Veni, 2019).

Moreover, the expansion in the productivity of a bank is constantly made a difference by the synthesis of benefits and risk. Non-performing resources become exceptionally urgent issues for the banks while expanding credits and generating profitability. Nonperforming assets (NPAs) can be Gross NPAs and Net NPAs. Non-performing advances raises to such a degree, that income tumble off and advance misfortune costs, just as working expenses connect all the incomes that proceed. The reasons for NPAs incorporate debacle, infection of the ventures, in successful recuperation process, business cycle, loaning strategy, nonattendance of checking and catch up credit and administrative issues. Non-Performing Assets show the fitness of the exhibition of the banks and it influences the money foundation as well as the all out monetary framework (Dudhe, 2014).

Furthermore, the primary wellspring of income of banks is through the premium earned on credits and advances and re-installment of the principal. On the off chance that such resources neglect to create pay, at that point they are named non-performing assets. As indicated by the Nepal Rastra Bankk (NRB) NPA is characterized as a credit office in regard of which the premium or potentially portion of principal is "past due" for a predefined period. For the most part, if the loan payments have not been made for a time of 90 days, the investment is named non-performing resource. Based on to what extent the advantage has been non-performing; banks are required to sort the non-performing assets in one of the accompanying classes:

- Pass: If an asset has been non-performing up to 3 months and bank should maintain $1 \%$ loan loss provision;

- Sub-standard asset: If an asset has been non-performing from 3 to 6 months and bank should maintain $25 \%$ loan loss provision;

- Doubtful asset: If an asset has been non-performing from 6 to 12 months and bank should maintain 50\% loan loss provision and

- Loss assets: If assets have been non-performing from more than 1 year and bank should maintain 100\% loan loss provision.

The generation of poor loans in the books of banks is not a favorable event for the banking industry as it affects the size and soundness of the balance sheet. There is an unfavorable impact on the level of return on assets as well. Large amount of profits have to be provisioned against the doubtful and bad loans, which reduces profitability. Banks are even burdened with the increasing level of carrying costs of NPA accounts, which could have been used for any other profitable purpose. The financial institutions are also desired to maintain a certain capital adequacy level to strengthen their net worth, which is not 
favorable for the banking industry. The NRB has been taking measures to control the NPA menace. Some legal measures such as 'insolvency act 2063' have been published in Nepal Gazette in 22 November 2006. Debt recovery tribunals (DRTs), 'unified directives 2074' by NRB have been introduced for the resolution of NPAs. Bank merger policies in recent years have been added.

Azeem (2014) examine the impact of (non performing loans) NPLs on profitability in Bank of Panjab and revealed that there is negative impact of NPLs on profitability, while stock return was not affected by NPLs. Furthermore, study of Khan, Siddique, \& Sarwar (2020) show that the operating efficiency and profitability indicators have a negative association with NPLs but were statistically significant, while capital adequacy and income diversification have a negative association with NPLs but were statistically insignificant. The standard measures of bank earnings are return on assets (ROA), return on equity (ROE) and net interest margin (NIM). ROA is one of the significant indicators of the overall efficiency of bank, and it is the most widely used indicator of the profitability. ROA descends because of different factors, for example, high NPAs, low charge based pay, lower level of capital sufficiency, high intermediation costs due to overstaffing, lower noninterest pay, and so on, and may prompt cut off bank trouble or disappointment. Saves money with higher overall revenues can continue the macroeconomic stuns and forestall its disappointment during budgetary emergency. Further, it is settled that bank's gainfulness has been adversely connected with bank's assets quality (Anastasiou, Louri, \& Tsionas, 2016;Fan \& Shaffer, 2004; Ghosh, 2015; Makri, Tsagkanos, \& Bellas, 2014; Seenaiah, Rath, \& Samantaraya, 2016).

\section{Statement of problem}

This study is oriented toward solving the problem by answering what the contribution of the different banks individually to the NPA in the industry by looking into its profitability trend over the period of 2013 July 16 to 2018 July 16. Further, the study is made to look into the effect of different groups of banks, namely, government and non-government banks on the banking industry in this regard. The following research questions have been set. Does nonperforming asset impact the profitability of commercial banks in Nepal? And what is the current position of non-performing assets of commercial banks in Nepal?

\section{Objective of the study}

The following are the objectives of the study:

To examine the impact of non-performing assets on profitability of commercial banks in Nepal. 
To assess the existing position of nonperforming assets of commercial banks in Nepal.

\section{Methodology}

This is a significant zone of examination as it establishes the framework for the proposed work. The rightness and power of the discoveries rely upon the plan that is laid. For the current examination, the segments of the structure are as per the following:

Analytical research design has been applied for the investigation procedure and defined random inspecting strategy has been applied to choose the 5 example from 24 non government banks and 1 bank from 3 government banks. The investigation depends on information from the period 2013 July 16 to 2018 July 16. Secondary data has been considering for the analysis process, which is collected from the NRB website and concerned banks annual financial statement. The gross NPAs, credit deposit ratio (CDR), employee expenses over total operating expenses (EER) are treated as autonomous variable and ROA and earning per share (EPS) as needy variable.

\section{Analysis and Findings}

Table 1 depends on the five years information of six example banks. Accordingly the quantity of observation in every factor is 30 .

\section{Table 1: Nature of variables overall sampled banks ( $n=30$ for each variables)}

\begin{tabular}{llllll}
\hline Statistics & EPS & ROA & CDR & NPA & EER \\
\hline Mean & 35.15 & 1.90 & 84.68 & 1.55 & 38.81 \\
SD & 3.33 & 0.09 & 1.68 & 0.25 & 2.59 \\
CV & 0.09 & 0.05 & 0.02 & 0.16 & 0.07 \\
\hline
\end{tabular}

Source: Annual reports of sample banks

Table 1 shows the qualities of factors to portray the fundamental highlights of the information in an investigation. They give straightforward outlines about the example and the measures in total. The measurements portrays blended outcome about highlights of information for various variable. The mean estimations of EPS, ROA, CDR, NPA and EER shows average position individually. Furthermore standard deviation (SD) and coefficient of variation $(\mathrm{CV})$ are the proportions of outright and relative inconstancy. With this regard, it has been watched more consistency as for the $\mathrm{CDR}(\mathrm{C} \mathrm{V}=0.02)$ though, greater instability has been seen as for the NPA $(\mathrm{CV}=0.16)$. 
Table 2: Relationship analysis of the variables.

\begin{tabular}{llllll}
\hline & EPS & ROA & CDR & NPA & EER \\
\hline EPS & 1 & & & & \\
ROA & 0.7208 & 1 & & & \\
CDR & -0.4372 & 0.0771 & 1 & & \\
NPA & 0.2557 & 0.4899 & 0.4335 & 1 & \\
EER & 0.6369 & -0.4795 & 0.4555 & 0.1081 & 1 \\
\hline
\end{tabular}

Source: Annual reports of sample banks.

Table 2 presents the relationship between's the arrangements of factors. As indicated by the idea of productivity, earning per share is one of the significant wellsprings of benefit. The outcome supports such an idea. The relationship of EPS on ROA appears to be $72.08 \%$. Nonetheless, these two have been considered in this investigation as reliant factors and consequences for these by the free factors have been assessed independently with the regression models.

The outcome of the relationship analysis revealed that there is positive relationship of EPS with NPA and EER where as ROA have positive relationship with CDR and NPA and Opposite relationship with EER.

\section{Table 3: Regression Result of the effect of CDR NPA and EER on EPS}

\begin{tabular}{ccccc}
\hline Variable & Coefficients & Standard Error & T Stat & P-value \\
\hline Constant & 120.9303 & 21.7291 & 5.5654 & 0.00001 \\
CDR & -0.8405 & 0.2941 & -2.8495 & 0.0085 \\
NPA & 6.5636 & 1.7755 & 3.6967 & 0.0010 \\
EER & -0.6390 & 0.1739 & -3.6752 & 0.0011 \\
\hline $\mathrm{R}^{2}=0.6283 ;$ Adjusted $\mathrm{R}^{2}=0.5854 ;$ F-stat $=14.64890 ;$ F-sig $=8.756 \mathrm{E}-06$ & \\
\hline
\end{tabular}

Source: Annual report of sample banks

Table 3 presents the regression consequence of the impact of CDR, NPA, and EER on one of the intermediaries of profitability, EPS. The consequences of $R^{2}$ and adjusted $R^{2}$ speaks to the level of the changeability of dependent variable can be clarified by the autonomous variable. These outcomes express the general informative intensity of the regression model. The estimation of $\mathrm{R}^{2}$ and adjusted $\mathrm{R}^{2}$ are 0.6283 and 0.5854 individually. This demonstrates most extreme $62.83 \%$ of the variety in the earning per share can be clarified by the variety in the logical variable. Based on these outcomes, it can't be guaranteed as solid generally logical intensity of the regression model is reasonable and factually fitted. The size of the coefficient for autonomous variable gives the size of the impact on subordinate variable. The sign on the coefficient provides the direction of the impact. 
The outcome shows that the coefficient of credit deposit ratio is - 0.8405 and factually critical at 5 percent level ( $p$-value $=0.0085$ ). The finding of this investigation clarified that credit deposit ratio significantly affects bank profitability. The outcome shows that for every addition in CDR prompts decline in EPS by 0.6283. As it were, for each extra CDR the normal EPS decline by a normal of 0.6283 . Be that as it may, hypothetically there is beneficial outcome among EPS and CDR, so the outcome is just factually noteworthy however not hypothetically. Further, the result indicates that, the effect of nonperforming asset ratio is positive and statistically significant $(\mathrm{P}-$ Value $=0.0010)$. The coefficient of employee expenses ratio revealed that there is negative impact of it on earning per share which is statically significant too $(\mathrm{p}=0.0011)$.

Table 4: Regression results of the effects of CDR NPA, and EER on ROA

\begin{tabular}{lllll}
\hline Variable & Coefficients & Standard Error & T Stat & P-value \\
\hline Constant & 1.8221 & 0.6713 & 2.7144 & 0.0116 \\
CDR & 0.0072 & 0.0091 & 0.7939 & 0.4345 \\
NPA & 0.1831 & 0.0549 & 3.3386 & 0.0025 \\
EER & -0.0212 & 0.0054 & -3.9382 & 0.0005 \\
\hline
\end{tabular}

$\mathrm{R}^{2}=0.5381 ;$ Adjusted $\mathrm{R}^{2}=0.4848 ; \mathrm{F}$-stat $=10.0971 ; \mathrm{F}$-sig= $1.3765 \mathrm{E}-04$

Source: Annual reports of sample banks

Table 4presents the regression results of the effect of credit deposit ratio, nonperforming asset and employee expenses ratio on one of proxy of profitability, ROA. The value of $\mathrm{R}^{2}$ and adjusted $\mathrm{R}^{2}$ are 0.5381 and 0.4848 respectively. This indicates that maximum 53.81 of the variation in the return on asset can be explained by the variation in the explanatory variables. The p-value for F statistics in the model represent that the model is fairly fitted well statistically. The F- significance in the model represent that the model is fairly fitted since it is less than 0.01 . Thus, the overall explanatory power of the regression model is fair and statistically fitted.

The result indicates that, the coefficient of credit deposit ratio is positive and statistically insignificant $(\mathrm{P}$-value $=0.4345)$. The result reveled that credit deposit ratio has a positive and significant impact on bank profitability.

Further the result indicates that, the effect of nonperforming asset ratio is not negative and statistically significant at five percent level $(\mathrm{P}$-value=0.0025). There is a positive impact of nonperforming assets on banks ROA which is the indicator of profitability. The outcome can be explained with aggressive policy of bank and stringent policy of regulatory body of Nepalese commercial bank. Aggressive policy accelerates the NPA whereas more investment gives more return. 
Moreover, the impact of employee expenses ratio on ROA is negative and significant (Pvalue $=0.0005)$.

\section{Discussion:}

Overall findings of this study concluded that impact of nonperforming loan on profitability in Nepalese commercial bank shows the positive impact. Higher risks beget higher return, we find evidence that nonperforming assets influence profitability positively it is very difficult to predict in contrast with high lending rate and aggressive policy that cause the increment in nonperforming assets too, which is the similar result with (Laryea, NtowGyamfi, \& Azum, 2016). Similarly the result of the study is contradictory with (Gnawali, 2018).

\section{Conclusion:}

The banks generate their income from the loans and advances which are disbursed and if these loans are not repaid then it's not possible for them to get profits. If the banks' profitability is affected then the total economy is affected. But in the Nepalese scenario Aggressive policy of the banks accelerates the NPA whereas more investment gives more return. On the other hand the developing phase of the economy on nation borrowers repaid their loans and advances not in time but stringent policy of regulatory body ultimately all dues are paid. the overall finding of the study on its first objective reveled that there is positive impact of NPA on profitability of Nepalese commercial banks, which is estimated by earning per share and return on assets.

Furthermore, sample of government owned bank has highest amount of nonperforming loan in comparison to private sector bank. So, government owned banks should decrease its nonperforming loan. On the other hand, private sector bank has lowest nonperforming asset implies that this bank has quite good policy in lending. The assessment of private sector banks reveals that the growth rate of NPAs is low as compared to the government owned Bank. The government owned bank has failed to handle the issue of poor loans effectively due to which the growth in such loans has been phenomenally high.

\section{References}

Anastasiou, D., Louri, H., \& Tsionas, M. (2016). Determinants of non-performing loans: Evidence from Euro-area. Finance Research Letters, 18 (c), 116-119.

Azeem, A. (2014). Impact of Profitability on Quantum of Non-Performing Loans. International Journal of Multidisciplinary Consortium, 1 (1), 1-14. 
Dudhe, C. (2014). Impact Of Non-Performing Assets On The Profitability Of Banks Â€“ A Selective Study. Annals of Faculty of Economics, 1, 307-314.

Fan, L., \& Shaffer, S. (2004). Efficiency versus risk in large domestic US banks. Managerial Finance, 30 (9), 1-19.

Ghosh, A. (2015). Banking-industry specific and regional economic determinants of non-performing loans: Evidence from US states. Journal of Financial Stability, 20 (c), 93-104.

Gnawali, A. (2018). Non-Performing Asset and its Effects on Profitability of Nepalese Commercial Banks. International Journal of Research in Business Studies and Management , 5 (9), 39-47.

Khan, M. A., Siddique, A., \& Sarwar, Z. (2020). Determinants of non-performing loans in the banking sector in developing state. Asian Journal of Accounting Research, 5 (1), 135-145.

Laryea, E., Ntow-Gyamfi, M., \& Azum, A. (2016). Nonperforming loans and bank profitability: evidence from an emerging market. African Journal of Economic and Management Studies , 7 (4), 462-481.

Makri, V., Tsagkanos, A., \& Bellas, A. (2014). Determinants of Non-Performing Loans: The Case of Eurozone. Panoeconomicus, 61 (2), 193-206.

Nachimuthu, K., \& Veni, M. (2019). Impact of non-performing assets on the profitability in Indian scheduled commercial banks. African Journal of Business Management, 13 (4), 128-137.

Pokhrel, B. P. (2020). Impact of non-performing assets on profitability in Nepalese Commercial Banks. Journal of Finance, 10 (1), 5-18.

Seenaiah, K., Rath, B. N., \& Samantaraya, A. (2016). Determinants of Bank Profitability in the Postreform Period: Evidence from India. Global Business Review, 16 (5S), 82S-92S. 